UDC 79.091:004.738.5

DOI: 10.18523/2617-8907.2021.4.99-105

Zhanna Shkliarenko

\title{
PERFORMANCE ART: INTERART, INTERMEDIALITY AND INTERDISCIPLINARITY
}

\begin{abstract}
At the end of the $20^{\text {th }}$ century performance art, as a rule, avoids pigeonholing itself as a separate form of the creative process, particular scientific orientation, or a definitive kind of art; it is an art of subliminal hints that everyone can perceive at their own discretion. Performance art involves mandatory involvement of the public and active communicative function. In an attempt to draw the attention of the public to the problem in performance art irony, epatage, exaggeration, metaphor, and association highlights of social phenomena that provoke the viewer indirectly or directly to some action or reflection on certain social issues, connecting the moment of interactivity are widely used. In addition, public art, which includes performance art, focuses on the unprepared spectator and involves communication with the city's space and its inhabitants. Democracy in performance art is manifested through the choice of a topic that can relate to any aspect of life. All performances art in the early $21^{\text {st }}$ century are united by external orientation, having an onlooker in mind, but any individual performance art is aimed at the idea of awakening the mind of the viewer.
\end{abstract}

Keywords: art of action, contemporary art, interdisciplinarity of performance, interdisciplinarity of performance art, live art, media art, performance art, public art, social art.

Problem statement. Performance art ${ }^{1}$ is an example of contradiction and multidimensionality in culture. Intermediality and interdisciplinarity are the main components of the phenomenon. The basis of performance art is the principle of provocation, only one of the three forms of which is acceptable within the scope of a creative act. Performance art potential does not simplify creative manifestation in the social sphere, on contrary, it allows an individual to extend beyond separate disciplines, thus obfuscating and enriching them. Due to interdisciplinarity, intermediality, and its contradictory nature of performance art the process of convergence and mutual reinforcement of creative act in particular branches is enabled.

Scale of scientific research. Performance art is for the first time understood and studied within a multidimensional cultural context. Multidisciplinary character and intermediality of performance art as a phenomenon are discussed at length. The study uses an approach that involves the analysis of imagery and symbolism, as one of the methods of studying non-verbal communication. Synthesis is used to combine discrete concepts with regard to their relationship to performance art with the creative forms of act within culture. An assessment of the

1 The term "performance art" is used to identify the phenomenon of short-lived corporal composition created in the public space, where the gesture is the main expressive means, and epatage and provocation are its organic properties. form and content of the phenomenon as a whole gives an opportunity to characterize the types of performance art in the contemporary media space.

The aim of the article is to identify possible random and intentional interdisciplinary and intermedial links of performance art with different kinds of arts as well as to study its miscellaneous scholarly research directions, and to substantiate the distinctive features of its manifestations in the given socio-cultural sphere. The article is concerned with interaction of various forms of performance art, which in their turn function as part of a unified cultural whole. A salient feature of performance art is its diffusive nature, along with the difficulty of recognising this phenomenon even by experts. The main objective of our research is to trace the characteristics of the connections and manifestations of performance art in culture.

Presentment of the basic material. The cultural space of a modern individual varies with its characteristics constantly changing from logocentric to visual-centric ones, from the analytical one, with its inherent longing for differentiation of sciences, to the comprehensive and interdisciplinary one, which closely resembles the uniform course of real life, the one that does not condone any division into faculties. Image-making experience of performance art (Арт-Азбука 2007; Wainwright 2020) is rooted in the act of revealing cultural phenomena through visualization, contemplation and reflection, while 
appealing to interdisciplinarity and intermediality (phenomena come from Literary, Media, Communication, General Semiotics and Arts Studies and operated by transdisciplinary tools), to simultaneous thinking and goes to make doubling of meaning, the connotative extension of images and return to the new, not original, text as a mechanism relevant creative thinking (Queiroz 2019; Clüver 2007; Хаминова 2015).

In the modern socio-cultural reality there are significant changes associated with the spread of performance art (Latin "perform" - "action"): the significant amount of information a mass recipient seeks to evaluate without venturing too deep into its verbal content, giving preference to the sensory part. Performance art is more quickly perceived and remembered by a respondent's consciousness; it activates persistent stereotypes and associations, whilst relying heavily on the performative, which is a part of the context of life events, that creates a social, communicative and interpersonal situation with consequences, and is self-referential, that is, it points to its own self-fulfilling action with expanded interpretation.

In addition to cultural approach, the study of performance art requires aspects of both art and philology due to multidimensional, intermedial nature (Hansen-Löve 1983, 291-360) of this concept, which combines literature and music, pictorial and theatrical, ritual and formal-structural analogies of existing artistic forms. The metaphorical, thematic, formal presence of one art in another, or the synthesis of arts are present in performance art for mutual reinforcement of the codes of various arts, in order to achieve archaic syncretism, that is, a single holistic action to convey certain emotional states. In addition, via the act of borrowing by performance art the codes of other cultures, arts, sciences, etc., there is interaction and the enrichment of these forms that is at play. Information transferring during performance art is a game of continuous semiotic invasion of one semiotic structures by others; this process creates new meaning, contributes to the emergence of new information, and its encryption with multiple codes emphasizes the communicative component of the performance art (Лотман 1992, 92-143).

Rapid development of communication and rising tendency to use its wide range of possibilities have led to the spread of intermediality through performance art that can be further differentiated into: hybridizational intermediality (that presupposes synthesis of species), transmedial intermediality (the embodiment of a single plot with the help of different arts), ontological intermediality (multimodality) and transformational intermediality (transcoding one sign system into another with empathy involved) (Тимашков 2012, 7-11). Performances of Nam June Paik "Zen for Film" (1962) (Bard Graduate Center Gallery 2016), Chris Burden "Velvet Water" (1974) (DonSimmons 2001), Oksana Chepelyk "Deaf-mutes Chorus" (Open Archive of Ukrainian Media Art 2004), Stelarc "Ear on Arm, Engineering Internet Organ" (2008), Ivan Svitlichny "Total Audio Performance Art" (PinchukArtCentre 2018) are impossible without new science-technological experience.

In performance art a work of art and the process of its creation are unanimous. Therefore, this practice combines the subject matter of knowledge and influence, that is, mergence of the object with the subject. Principles, laws, and categories of these phenomena are the basis of the research of philosophy and psychology. Philosophy, in terms of performance art, could be considered its theoretical and methodological basis. Psychology, along with behavioural practices, natural sciences and its branch, biological science, underlies the practical, experimental nature of performance art.

In art, since special reality is construed for art purposes, performance art can yield a strong effect on emotional states in the terms of closeness between a viewer and an artist. An unusual antitheatricality of an actor-performer is likened to the psychological image of a trickster: the mythological character of Native Americans. The manifestation of behavioural creativity in routine actions has long been considered indispensable for the artistic understanding of life as art. The researchers of art claim that art does not always require (specific) institutions (Лидерман 2010; Яцик 2008), that is, it is possible beyond exhibition halls of galleries, museums, etc., and can be created by people who do not consider themselves to be artists; so the separation line the lies between life and art is rather conditional.

There has been found a direct link between performance art and other disciplines: primarily with sociology, politics, history, since they are humanities, and take into account processes inherent in separate individuals, large and small social groups. Performance art can bring together people of different cultures, create communication bridges within separate societies, and establish intercultural connections. Performance art phenomenon also points to vital life values of an individual, group or society. From the moment it has been established till present performance art has been involving new possible means of expressiveness as well as methods of non-verbal communication. 
It is proved that performance art has a number of features inherent to it as a cultural phenomenon. Firstly, the multi-layered system of collective beliefs with cultural codes imbedded forces the audience to perceive performance art in a certain way. Secondly, social power in the form of censorship reacts to a content of performative art or to its part; this action in itself is as an indicator of humanness and humanity of the current societal order. Thirdly, audience decrypting symbolic texts (coded by the actor) varies from a direct one (viewers in the hall) to an indirect and random (viewers and passers-by) audience (Лидерман 2010). What is more, the actor involved does not require special training and an example of this are project "Inclusion in Culture" (Гете інститут 2020), of Goethe-Institut Ukraine and performance "Creativity of Down Syndrome People" (2018).

The link between the performance art, linguistics, and anthropology is also apparent, since the coining of the artistic term, "performance art", is owned to the speech acts theory by J. Austin. Thus, performance art is associated with a first person sincere verbal statements in indicative mood, which is a prerequisite for the existence of various social groups. As a result of anthropological studies on a rite of transition, V. Turner has determined a liminal part (interim phase), which reveals the entire performative potential, the meaning of behavioural metamorphosis.

The interdisciplinary connections within performance art indicate the search for new ways of solving complex problems in the synthesis and integration process: one may observe a shift from one set of disciplines (to which one apply interdisciplinary aspects) to new disciplines with a new subject of research: a look-out for a holistic understanding of the universal scientific world picture, which is constantly further complicated in its strive to cover more and more phenomena of reality. The connection of performance art, as a cultural phenomenon, to science is followed by the emergence of new, still unknown forms of art on the basis of scientific and technological progress and performance art. These include VJ-performance, contemporary dance, etc. At the same time, technical innovations which have no practical application in the present time are nothing more than performance art, but subsequently have the chance to transform into future scientific achievements and various extreme sports that are constantly evolving due to technical possibilities in conjunction with creativity: freifeil (FreeFly), any king of jumping (B.A.S.E. jumping, bungee jumping; rope jumping), etc., or vice versa: sports with complete deliberate rejection of any technical assistance, such as parkour.

In the $20^{\text {th }}$ century performance art strengthens the view on experiment as a reflection of the constant attempts and risks of modern life, in which traditional rank script forms of behaviour are ineffective and invalid. This form of creativity reveals the symbolic significance of the experiment as a social action the best (Никитина 1997). Due to its ability to mimic corresponding emotional states and to lure us back into the world of feelings and sensations by copying familiar action via the usage of artistic means, performance art adds extrapolation into the art-process, that is, by applying separate conclusions on the whole multiplicity of phenomena: the unknown draw upon the known, the future is imagined in terms of the past and the present.

The performative "statements" in particular and the language of art as a whole have become bolder, and the means employed by modern artists make it possible to express themselves quickly without involving traditional forms of arts. Thanks to performance art contemporary artistic practices acquired the following performative characteristics as: hyperrealism that allows to cross the usual limits of perception of an artistic work; the game/ game-likeness; the absence of a single author; provocativeness of actions; collectiveness; the teleological (in the sense of anthropocentric reimagining) vector of the art-process, suggestibility (the ability to perceive psychological influence from another person or group), a new role of man and body (Романюк 2010).

It should be mentioned there is that there is a distinct difference between creative acts and political actions. In a pragmatic and rational political action, the form of relationship with the audience is different from that one in performance art in: its views (a political action is the form of their fossilization, whilst performance art seeds doubt when it comes to popular views); the audience (for a politician it is either an opponent or a supporter, for a performer, i.e. a thoughtful and critical contributor and a co-author); the author (a politician plays the audience, while a performer is with the audience). A. Vujanović (Вуянович 2013), a theoretician of performative practice, believes that any performance art intervenes and interferes with the social environment, affects the public space by using new images, depictions, techniques of work with a body and society. The researcher singles out models of politically, presented in modern studies: Political content; Politically of the performance medium and form; Politically of modes of work production. In the 
model of "Political Content" art takes the place of a third-party observer in social events, where one can talk about social events, without being directly involved in them. The model of "Politically of the performance medium and form" may not have a direct political message or content, but only political potential. The model "Politically of modes of work production" covers the pattern-consistency of cooperation principles, the setting in the context of economic conditions, the ways of forming groups, etc.

The majority of independent groups engaged in performing avant-garde art practices use traditional hierarchical elements of official theatrical institutions: director, actors, agents, etc. The problem of theatricalization of politics and perception of political events through the prism of entertainment and showmanship is elucidated through the interdisciplinary links between media performance and politics. This does not mean that art is a politics, but it presupposes art to be its component as in Liashko's performances (Ляшко 2011, 2013, 2016).

The potential of the provocative avant-garde art has convenient forms for using art as a cover-up for one's satisfaction of pathological needs. Therefore, it is important to have a clear distinction between the unusual forms of artistic avant-garde and the cocalled "artistic" mendacious portrayal of events that are in fact violent in their nature or are violations of the rights of an individual, regardless whether they were produced by an actual artist.

To understand the nuances of differences between various kinds of "provocation" and manipulation, the experience of social psychology might be useful. In particular, the candidate of psychological sciences and the practicing performer E. Morozova (Mopozoва 2005, 22) divides provocativeness, which is widely used in performance art, into the following groups:

1) its linguistic non-specific definition (Latin "provocation" - "challenge"), which involves the influence of one object on another (control, the challenge in an object's state, attention attraction regardless of the object's volition);

2) an act of evocation of anger, incitement associated with conflict, confrontation, attack, scandal, deception, violence, shock, etc. An action that harms an object of influence with a provocateur in interest. This group is divided into two subgroups: the open - the obvious pushing of the object of provocation to the actions favourable by provocateurs, which hurt the very object of provocation, hidden - the actions of the provocateur are imperceptible to the consciousness of the object of influence);
3) the act of encouragement, prompting, inviting, stimulating, motivating, calling for action, in which there are no negative components. The psychological impact of the third group, like the previous ones, may be intensive and accompanied by negative experiences, but the intention of the provocative side is not destructive to the object of influence. It is this group of provocations that is characterized by the stimulating potential of catharsis.

However, attempts to artificially bring performance closer to criminalistics through terrorist acts are unacceptable. Still the terrorist acts have nothing to do with the creative process due to the difference in the ultimate goal: in the performance it is creative and restorative, in a terrorist act the goal is destructive. $\mathrm{V}$. Romaniuk draws attention to the fact that terrorist acts are sometimes called performances, because they have common features: a flexible changing scenario; the participation of statisticians, who may become casual passers-by; the presence of appropriate scenery; open public space; carefully thought out actions; unimportant accomplices, observers and critics play a crucial role; collective metamorphosis (Романюк 2010, 150), but highlights the significant difference between them: performance is "living art", terror is "deadly" (Дорош 2014).

Despite the fact that behavioural psychologists, psychoanalysts and pathophysiologists are engaged in dissection of the term, there are performance art that are complicated to recognise even for specialists up to the complete dissipation of the action or intervention of public order guards, as it happened at the Art Basel exhibition in Miami Beach 2015. The conflict of the visitor with the curator of the exhibition turned into a fight with a knife, and the audience perceived this as a performance act and did not help the wounded curator (Wooldridge 2015).

Various technical possibilities allow the art of performance to spread to the media sphere, bringing in new art for synthesis such as: video art (work with video and television images); telecommunication-art (famous artworks use well-known kinds of virtual space); video installations (constructions from television or video devices); net-art (ever-changing network art that is transformed Internet by users).

This is facilitated by the interactive devices of high-tech culture of our time. In this case, original derivations from performance art are formed: media performance art - the genre of the media using the entire spectrum of telecommunication systems, and the interaction of the author and participants in the network; video performance art - a performance art on the verge of genres with the experiment "for the camera-roll"; flashmob - an action with prior arrangement and analysis in social networks. 
Media-related performances have components that are characteristic of other types of living art. Among them: collective creativity; overcoming cultural boundaries for the purpose of "equal dialogue", search of new possibilities of communication; expanding artistic opportunities at the expense of the latest technical means; the use of opportunities for perception of art through the virtual space; removal of geographical boundaries for the sake of art; an attempt to create a non-profit form but they also depend on the technological possibilities of digital media and can be instantly transmitted to receivers all over the globe, and can be designed to invite the interaction of a global community (Романюк 2010; Clüver 2007). Such as performances of young Brooklyn-based artist Man Bartlett who works through social media platforms like Twitter, Tumblr, and Facebook because the role of the artist is to respond to society and the times they live in (Blouin ArtInfo 2012).

In online communities, social networks and other intellectual communities, in addition to network art, there are many similar phenomena with performative features of collective authorship forums, encyclopaedias, multivariate ideas of the community, and the lack of restrictions in the implementation of the author's plan, the process of involving participants and using tools that urge to be involved in communication. Performance art is also the subject of discussions, in which groups, which are not engaged in its creation and not present during the performance act, but, nevertheless, show great interest in it. The search for "art in non-art" at the present is equivalent to media promotion and media success, that is, the "significance" of a work of art is determined by voting or by the number of views ("likes") on the network. According to various facts of the use of political activism joined with the implementation of artistic techniques and their interpretation, the deficiencies of society are becoming apparent, which is very prominent in the art of performance.

Conclusions. Hence, intermediality and interdisciplinarity are the main components in the controversial and multidimensional performance art culture. The basis of performance art is the principle of provocation, only one of the three forms of which is an acceptable creative act. The performance potential does not simplify creative manifestations in the social sphere, it allows one to go beyond the limits of separate disciplines and make them more complex and rich. The performance points to the dynamics of societal culture, reveals the cultural differences of society, is formed on the basis of interdisciplinary interactions and synthesis, evolves through the exchange between different sciences. Through interdisciplinarity, intermediality, and its contradictory nature, performance art enables the process of convergence and mutual reinforcement of creative processes in particular branches.

\section{Список використаної літератури}

Арт-Азбука. Перформанс. URL: http://azbuka.gif.ru/alfabet/p/ performance/ (дата звернення: 12.02.2021).

Відкритий архів українського медіа-арту. Оксана Чепелик «Хор глухонімих». 2004. URL: http://www.mediaartarchive.org.ua/ media-art/khorglukhonimikh/ (дата звернення: 12.02.2021).

Волков В. Интермедиальность как атрибут художественности (лингвогерменевтика термина). Вестник Российского университета дружбы народов. Серия: Теория языка. Семиотика. Семантика. 2014. Т. 2. С. 135-142.

Вуянович А. Перформативные искусства, активизм и социальные изменения. 2013. URL: http://ziernie-performa.net/ blog/2013/10/16/ (дата обращения: 12.02.2021).

Гете інститут. Інклюзія в культурі. 2020. URL: https://www. facebook.com/watch/?v=258522931512748 (дата звернення: 12.02.2021).

Гете інститут. Креативність людей з синдромом Дауна. 2018. URL: https://www.goethe.de/ins/ua/uk/m/ver. cfm?fuseaction=events.detail\&event_id $=21792657 \&$ (дата звернення: 12.02.2021).

Дорош М. Вікторія Романюк: публічне знущання під спалахи фото- та відеокамер над пораненими є спланованим шокуючим приниженням всієї України. 2014. URL: https:/ ms.detector.media/tip-intervyu/post/11424/2014-08-26viktoriya-romanyuk-publichne-znushchannya-pid-spalakhi-fotota-videokamer-nad-poranenimi-e-splanovanim-shokuyuchimprinizhennyam-usiei-ukraini/ (дата звернення: 12.02.2021).

Лидерман Ю. Почему концепция перформативного искусства не популярна в сегодняшней России? Вестник общественного мнения. 2010. № 3. С. 37-45.
Лотман Ю. Избранные статьи : в 3 т. Т. 1 : Статьи по семиотике и типологии культуры. Таллинн : Александра, 1992. 480 c.

Ляшко О. Ляшко цілує святу українську землю. 2011. URL: https:// www.youtube.com/watch?v=V34DPC0v65k\&t=517s (дата звернення: 12.02.2021).

Ляшко О. Ляшко мовою Азарова у BP. 2013. URL: https://www. youtube.com/watch? $\mathrm{v}=\mathrm{rXBOnU} 5 \mathrm{~J} 2 \mathrm{~A}$ (дата звернення: 12.02.2021).

Ляшко О. Ляшко: Україна починається 3 корови. 2016. URL: https://www.youtube.com/watch? $=7 \mathrm{k} 1 \mathrm{NuNWtZv} 0 \& \mathrm{t}=26 \mathrm{~s}$ (дата звернення: 12.02.2021).

Морозова Е. Социально-психологическое исследование художественной провокативности (на примере современного авангардного искусства) : дис. ... канд. психол. наук / Московский пед. гос. ун-т. Москва, 2005.

Никитина Л. Феномен синтеза искусств в отечественной культуре конца XIX - начала XX в. Творчество и культура : Материалы Всерос. науч.-практ. конф. Екатеринбург, 1997. С. 114-118.

Романюк В. Перформанс у просторі культури: архаїчні прототипи та сучасні репрезентації : дис. ... канд. культурології / Харківська державна академія культури. Харків, 2008.

Савчук В. Конверсия искусства. Санкт-Петербург : Петрополис, 2001.

Тимашков А. Интермедиальные стратегии авторов «футуристической оперы» «Победа над солнцем» (А. Е. Крученых, М. В. Матюшин， К. С. Малевич， В. В. Хлебников， 1913). Literatūra. 2012. T. 2. C. 7-11.

Тимашков А. К истории понятия интермедиальности в российской и зарубежной науке. Žmogus ir žodis. 2007. T. 11. C. 112-119. 
Хаминова А. Интермедиальность: от метафоры к технологии. Гуманитарная информатика. 2015. Т. 9. С. 80-87.

Яцик I. Public Art у сучасному просторі Києва. Інсталяція. Перформанс. Акціонізм. Сучасне мистецтвво. 2008. Вип. 1. С. 157-161.

Bard Graduate Center Gallery. Revisions - Zen for Film. 2016. URL: https://www.youtube.com/watch?v=pLshcm 24 ULA (date of access: 12.02.2021).

Blouin ArtInfo. Man Bartlett: The Social Media Artist. 2012. URL: https://www.youtube.com/watch?v=EhHiwJjkGms\&lis $=$ LLi4PAemUHtePDBPsNlQPgYQ\&index $=1230 \& \mathrm{t}=0 \mathrm{~s} \quad$ (date of access: 12.02.2021).

Clüver C. Contemporary Positions in Intermediality. Intermediality and Interarts Studies / J. Arvidson (Ed.). Lund: Intermedia Studies Press, 2007. P. 19-37.

DonSimmons. rePerformance: "Velvet Water". 2001. URL: https://www. youtube.com/watch?v=91fodkm7R60 (date of access: 12.02.2021).

Hansen-Löve Á. Intermedialitát und Intertextualitát. Probleme der Korrelation von Wort und Bildkunst - am Beispiel der russischen Moderne. Wiener Slavistische Almanach. 1983. Vol. 1. P. 291-360.

PinchukArtCentre. Іван Світличний - номінант Премії PinchukArtCentre 2018. 2018. URL: https://www.youtube. $\mathrm{com} /$ watch $\mathrm{v}=2 \mathrm{cKlo0IEgOA} \& \mathrm{t}=24 \mathrm{~s}$ (date of access: 12.02.2021).

Queiroz J. Intermediality, Transmediality, Multimodality and Intersemiotic Translation. International Journal of Semiotics and Visual Rhetoric. 2019. Vol. 3(2). P. 4-6.

Stelarc. "Ear on Arm, Engineering Internet Organ". 2008. URL: https://www.youtube.com/watch?v=k1 AhxTbMdF4 (date of access: 12.02.2021).

Wainwright L. Performance art. 2020. URL: https://www.britannica. com/art/performance-art (date of access: 12.02.2021).

Wooldridge J. Fight leads to woman stabbed at Art Basel Miami Beach. 2015. URL: https://www.miamiherald.com/entertainment/ visual-arts/art-basel/article48069515.html (date of access: 12.02.2021).

\section{References}

Art-Azbuka. "Performans." http://azbuka.gif.ru/alfabet/p/performance/ [in Russian].

Bard Graduate Center Gallery. 2016. "Revisions - Zen for Film." https://www.youtube.com/watch? $\mathrm{v}=\mathrm{pLshcm} 24 \mathrm{ULA}$

Blouin ArtInfo. 2012. "Man Bartlett: The Social Media Artist." https://www.youtube.com/watch?v=EhHiwJjkGms\&list=LLi4 PAemUHtePDBPsN1QPgYQ\&index $=1230 \& \mathrm{t}=0 \mathrm{~s}$

Clüver, Claus. 2007. "Contemporary Positions in Intermediality." In J. Arvidson (Ed.), Intermediality and Interarts Studies, 19-37. Lund: Intermedia Studies Press.

DonSimmons. 2001. rePerformance: “Velvet Water". https://www. youtube.com/watch?v=91fodkm7R60

Dorosh, Maryna. 2014. "Viktoriia Romaniuk: publichne znushchannia pid spalakhy foto- ta videokamer nad poranenymy ye splanovanym shokuiuchym prynyzhenniam vsiiei Ukrainy." https://ms.detector.media/tip-intervyu/post/11424/2014-08-26viktoriya-romanyuk-publichne-znushchannya-pid-spalakhi-fotota-videokamer-nad-poranenimi-e-splanovanim-shokuyuchimprinizhennyam-usiei-ukraini/ [in Ukrainian].

Goethe-Institut Ukraine. 2018. "Kreatyvnist liudei z syndromom Dauna." https://www.goethe.de/ins/ua/uk/m/ver.cfm?fuseaction= events.detail\&event_id=21792657\&

2020. "Inkliuziia v kulturi." https://www.facebook.com/ watch $/ ? \mathrm{v}=258522931512748$

Hansen-Löve, Aage A. 1983. "Intermedialitát und Intertextualitát. Probleme der Korrelation von Wort und Bildkunst - am Beispiel der russischen Moderne." Wiener Slavistische Almanach 1: 291-360.

Khaminova, Anastasiya. 2015. "Intermediality: from metaphor to technology." Gumanitarnaya informatika 9: 80-7. DOI: 10.17223/ 23046082/9/6 [in Russian].

Liderman, Yulia. 2010. "Why is Conception of Performance Art not Popular in Modern Russia?" The Russian Public Opinion Herald. Data. Analysis. Discussions 3: 37-45 [in Russian].

Liashko, Oleh. 2011. "Liashko tsiluie sviatu ukrainsku zemliu." https://www.youtube.com/watch?v=V34DPC0v65k\&t=517s

2013. "Liashko movoiu Azarova u VR." https://www youtube.com/watch?v=rXBOnU_5J2A

2016. "Liashko: Ukraina pochynaietsia z korovy." https://www.youtube.com/watch?v=7k1NuNWtZv0\&t=26s

Lotman, Juri. 1992. Izbrannye stati. In 3 vols. Vol. 1: Stati po semiotike i tipologii kultury. Tallinn: Aleksandra [in Russian].

Morozova, E. 2005. "Socialno-psihologicheskoe issledovanie hudozhestvennoj provokativnosti (na primere sovremennogo avangardnogo iskusstva)." Thesis $\mathrm{PhD}$ diss., Moscow Pedagogical State University [in Russian].
Nikitina, L. 1997. "Fenomen sinteza iskusstv v otechestvennoj kulture konca XIX - nachala XX v." In Tvorchestvo i kultura, 114-118. Ekaterinburg. https://elar.urfu.ru/bitstream/10995/ 28932/1/tvic_1997_47.pdf [in Russian].

Open Archive of Ukrainian Media Art. 2004. Deaf-mutes Chorus by Oksana Chepelyk. http://www.mediaartarchive.org.ua/mediaart/khorglukhonimikh/ [in Ukrainian].

PinchukArtCentre. 2018. Ivan Svitlychnyi - nominant Premii PinchukArtCentre 2018. https://www.youtube.com/watch? $\mathrm{v}=$ $2 \mathrm{cKlo} 0 \mathrm{IEgOA} \& \mathrm{t}=24 \mathrm{~s}$

Queiroz, João. 2019. “Intermediality, Transmediality, Multimodality and Intersemiotic Translation." International Journal of Semiotics and Visual Rhetoric 3(2): 4-6.

Romaniuk, Viktoriia. 2008. "Performans u prostori kultury: arkhaichni prototypy ta suchasni reprezentatsii." Thesis $\mathrm{PhD}$ diss., Kharkiv State Academy of Culture [in Ukrainian].

Savchuk, Valeriy. 2001. Konversiya iskusstva. St. Petersburg: Petropolis [in Russian].

Stelarc. 2008. “Ear on Arm, Engineering Internet Organ.” https:// www.youtube.com/watch?v=k1AhxTbMdF4

Timashkov, Aleksey. 2007. "K istorii ponyatiya intermedialnosti v rossijskoj i zarubezhnoj nauke.” Žmogus ir žodis 11: 112-9 [in Russian].

2012. "Intermedialnye strategii avtorov "futuristicheskoj opery" "Pobeda nad solncem" (A. E. Kruchenyh, M. V. Matyushin, K. S. Malevich, V. V. Hlebnikov, 1913)." Literatūra 2:7-11. DOI: 10.15388/Litera.2012.2.2466 [in Russian].

Volkov, Valeriy. 2014. "Intermedialnost kak atribut hudozhestvennosti (lingvogermenevtika termina)." RUDN Journal of Language Studies, Semiotics and Semantics 2: 135-42 [in Russian].

Vujanović, Ana. 2013. "Performativnye iskusstva, aktivizm i socialnye izmeneneniya." http://ziernie-performa.net/blog/2013/10/16/ [in Russian].

Wainwright, Lisa. 2020. Performance art. https://www.britannica. com/art/performance-art

Wooldridge, Jane. 2015. Fight leads to woman stabbed at Art Basel Miami Beach. https://www.miamiherald.com/entertainment/ visual-arts/art-basel/article48069515.html

Yatsyk, Iryna. 2008. "Public Art u suchasnomu prostori Kyieva. Instaliatsiia. Performans. Aktsionizm." Contemporary Art Ukrainian]. 1: 157-61. http://nbuv.gov.ua/UJRN/S_myst_2008_5 13 [in 
Жанна Шкляренко

\section{МИСТЕЦТВО ПЕРФОРМАНСУ: ПРОМІЖНЕ МИСТЕЦТВО, ІНТЕРМЕДІАЛЬНІСТЬ ТА ІНТЕРДИСЦИПЛІНАРНІСТЬ}

Незвичайне явище, помічене в другій половині XX ст. Дж. Остіном, Р. Шехнером, В. Тернером i назване тепер перформансом у різних наукових спрямуваннях, можна порівняти з пульсуючим протуберанцем, сонячним зайчиком чи водою. Адже щоразу, «спійманий», він залишає по собі абсолютно новітню форму, новий вид у мистецтві чи жанрове утворення. Кудись зникаючи, розчиняючись і стабілізуючись у культурі, з'являється згодом зовсім в іншому місці в інший час у непередбачуваний спосіб (це і $є$ його головна особливість), знову в невизначеній іпостасі. Навіть запозичена 3 англійської його назва залишає поле для роздумів: це вже не вистава, але й не показ/демонстрація, не продуктивність/ефективність, але рушійна сила. Так, він проявляється в інклюзії в культурі й креативності людей з синдромом Дауна, у витівках О. Ляшка та інших політиків, сучасних новоутвореннях спортивного та віртуального характеру тощо.

Уможлививши нове, перформанс водночас не $є$ чимось новим у культурі, але важливо, що саме в цьому явищі синтезуються новітні технології з традиційним мистецтвом та й із самим життям. Завдяки відсутності будь-якої лінії розмежування з щоденною креативністю, самодіяльною творчістю й утвореною а́кторами особливою реальністю, перформанс спроможний викликати потужні емоційні стани й відчуття взаємозв'язку людей у суспільстві.

Таке явище потребує ретельного вивчення, оскільки може поставати у вигляді зручної форми для маніпуляції, насилля й недбалого ставлення до людської гідності, здоров’я чи життя. Ця форма творчості не підпорядкована жодному прогнозу, контролю та є складною для впізнаваності навіть фахівцям. Розчиняючись у нових медіа та долаючи межі окремих дисциплін, така форма творчості залишається малозрозумілою, кожен може інтерпретувати ії у свій спосіб. Проте саме широкий потенціал цього інтердисциплінарного та інтермедіального культурного явища дає змогу віднайти приховані закономірності та складники проявів його існування в сучасному світі.

Ключові слова: живе мистецтво, інтердисциплінарність перформансу, інтермедіальність перформансу, мистецтво дії, мистецтво перформансу, соціальне мистецтво, сучасне мистецтво, публічне мистецтво.

Матеріал надійшов 12.03.2021

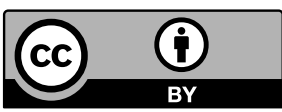

Creative Commons Attribution 4.0 International License (CC BY 4.0) 